\section{Foliar Sprays Containing Phosphorus (P) Have Minimal Impact on 'Pinot noir' Growth and P Status, Mycorrhizal Colonization, and Fruit Quality}

\author{
R. Paul Schreiner \\ USDA-ARS, Horticultural Crops Research Laboratory, 3420 NW Orchard \\ Avenue, Corvallis, OR 97330
}

Additional index words. arbuscular mycorrhizal fungi, phosphate, phosphite, Vitis vinifera

\begin{abstract}
Grapevines grown in low-phosphorus (P) soils typical of western Oregon vineyards may benefit from additional $P$ applied to the canopy using foliar sprays. Alternatively, vines may be negatively affected by foliar $P$ sprays because lower root colonization by arbuscular mycorrhizal fungi (AMF) could reduce uptake of other nutrients or increase vine water stress. The impact of foliar $P$ sprays on vine growth, vine nutrient and water status, AMF colonization, and fruit yield and quality was studied in two 'Pinot noir' vineyards with a history of low vine $P$ status over 3 years. Three foliar spray treatments [phosphite, phosphate, water (control)] were applied to vines three times each season using a standard air-blast sprayer at a commercial vineyard. Two foliar spray treatments (phosphite, water) were applied using a hand sprayer at a smaller research vineyard. Phosphite sprays increased leaf blade and petiole $P$ concentrations and reduced arbuscular colonization of roots at the research vineyard, but neither phosphate nor phosphite significantly affected these variables at the commercial vineyard. Foliar $P$ sprays had no effect on vine growth, vine water relations (leaf water potential and stomatal conductance), yield, or fruit quality attributes at either site. These results indicate that there is little benefit to spraying the canopy of grapevines with $\mathbf{P}$, even in vineyards with low $P$ status.
\end{abstract}

Spraying the foliage of grapevines with solutions containing nutrients can effectively improve micronutrient [particularly boron (B) and zinc $(\mathrm{Zn})]$ status of grapevines (Christensen et al., 1978; Cook, 1966). Indeed, most vineyard managers in western Oregon use foliar sprays of B (often mixed with fungicides) early in the season or postharvest to ensure that vines are not limited by this nutrient. Foliar sprays of macronutrients [nitrogen $(\mathrm{N})$, phosphorus $(\mathrm{P})$, potassium $(\mathrm{K})$ calcium $(\mathrm{Ca})$, magnesium $(\mathrm{Mg})$, sulfur $(\mathrm{S})$ ] have traditionally not been recommended for grape production, because these elements are needed in much greater quantities and uptake through leaves alone is not sufficient to be of

\footnotetext{
Received for publication 22 Jan. 2010. Accepted for publication 11 Mar. 2010.

I thank Matthew Scott, Stepfanie Lair, and John Carter for technical support and the staff at Benton Lane Vineyard \& Winery (Matt Compton and Phil Brey) for their help in applying foliar sprays and making separate wine lots from the trial. I am also grateful to Julie Tarara and Carolyn Scagel for reviewing and editing a previous version of this paper.

Mention of a trademark, proprietary product, or vendor does not constitute a guarantee or warranty of the product by the U.S. Dept. of Agriculture and does not imply its approval to the exclusion of other products or vendors that also may be suitable. e-mail paul.schreiner@ars.usda.gov.
}

practical use (Christensen, 2005). However, in citrus and apple orchards, foliar sprays of $\mathrm{N}$ alone can supply enough added $\mathrm{N}$ to meet tree demand and reduce nitrate leaching to groundwater (Dong et al., 2005; Embleton and Jones, 1974). Spraying grapevines with $\mathrm{N}$ can be an effective method to boost vine $\mathrm{N}$ status and increase berry $\mathrm{N}$, particularly in dry years (Cheng et al., 2003). Foliar sprays containing $\mathrm{K}$ have generally not improved vine $\mathrm{K}$ status when used in vineyards (Kasimatis and Christensen, 1976; Knoll et al., 2006). Foliar application of phosphate $\left(\mathrm{PO}_{4}\right)$ was recently reported to increase leaf $\mathrm{P}$ concentrations and improve fruit yield of 'Thompson Seedless' grapevines (Saleh et al., 2007).

Spraying the foliage of grapevines with $\mathrm{P}$ may be an effective method to boost vine $P$ status in western Oregon vineyards, because vines are predominantly grown on red-hill soils (Ultisols) that have very low levels of available P (Schreiner, 2005) and a high potential for P fixation. Sufficient levels of $\mathrm{P}$ for grapevines based on leaf or petiole $\mathrm{P}$ concentrations have not been established in western Oregon vineyards. Bloom-time petiole $\mathrm{P}$ concentrations below $1.0 \mathrm{~g} \mathrm{P} / \mathrm{kg}$ dry mass are considered P-deficient in California vineyards (Christensen et al., 1978). Yield responses to $\mathrm{P}$ fertilizers were noted in Australia when bloom-time petiole $\mathrm{P}$ values were above $1.0 \mathrm{~g} \mathrm{P} / \mathrm{kg}$ dry mass, which led to a suggested critical value of 2.0 (Robinson and McCarthy, 1985). Critical P concentrations in leaf blades (lamina) collected at bloom or véraison range from 1.2 to $1.6 \mathrm{~g}$ $\mathrm{P} / \mathrm{kg}$ dry mass (Gärtel, 1996; Robinson, 2005). However, $P$ levels greater than $1.8 \mathrm{~g}$ $\mathrm{P} / \mathrm{kg}$ dry mass were required in shoot tips before previously P-deficient (and stunted) vines had resumed shoot growth after application of $\mathrm{P}$ fertilizers (Cook et al., 1983). Additionally, shoot growth of young 'Pinot noir' grapevines inoculated with different arbuscular mycorrhizal fungi (AMF) showed a further increase because leaf blade $P$ concentrations rose from 1.5 to $2.1 \mathrm{~g} \mathrm{P} / \mathrm{kg}$ dry mass in different treatments (Schreiner, 2007). These studies indicate that $P$ supply may be too low whenever leaf blade or bloom-time, petiole $\mathrm{P}$ concentrations fall below $2.0 \mathrm{~g} \mathrm{P} / \mathrm{kg}$ dry mass.

Boosting vine $\mathrm{P}$ status with foliar $\mathrm{P}$ sprays could reduce the level of root colonization by $\mathrm{AMF}$ as shown previously in commercial vineyards in Oregon (Schreiner and Linderman, 2005). It is well known that increasing plant $\mathrm{P}$ status with $\mathrm{P}$ fertilizer can reduce AMF colonization in roots (Koide and Schreiner, 1992). A reduction in colonization brought about by foliar P sprays could decrease other benefits that plants derive from mycorrhizal symbiosis, including enhanced drought tolerance (Augé, 2001). Grapevines appear to be more dependent on $\mathrm{AMF}$ as more water stress is imposed under field conditions (Schreiner et al., 2007).

Fertilizers commonly contain $\mathrm{P}$ in the form of phosphate $\left(\mathrm{PO}_{4}\right)$. Phosphite $\left(\mathrm{PO}_{3}\right)$, which is derived from phosphorous acid, is being aggressively marketed as a fertilizer to grape growers. Phosphite is taken up by the same transporters as phosphate, is both phloem- and xylem-mobile, and appears to be sensed as phosphate by plants (McDonald et al., 2001; Ticconi and Abel, 2004; Varadarajan et al., 2002). Once inside plant cells, however, phosphite cannot be assimilated into organic compounds and metabolized as a substitute for phosphate. Because plants perceive phosphite as phosphate, plants given phosphite can become P-deficient without displaying typical $\mathrm{P}$ deficiency symptoms (increased root growth and root hair development, anthocyanin accumulation, induction of specific enzymes that circumvent P-requiring steps in basic metabolism or recycle phosphate from other metabolites) (Carswell et al., 1996; Danova-Alt et al., 2008). Plants given only phosphite as a source of $\mathrm{P}$ do not survive (Thao et al., 2008).

The purpose of this study was to evaluate whether foliar P sprays containing either phosphate or phosphite can be an effective method to increase grapevine $\mathrm{P}$ status in western Oregon vineyards and if these sprays, in turn, alter vine growth, AMF colonization of roots, plant water status, or fruit quality.

\section{Materials and Methods}

Study vineyards. Experiments were conducted from 2003 through 2005 in two 'Pinot noir' (Vitis vinifera L., Pommard clone, FPS 91) vineyards: a commercial vineyard (Benton 
Lane Vineyard; long. $44^{\circ} 17^{\prime} \mathrm{N}$, lat. $123^{\circ} 19^{\prime}$ W) planted in 1997 with spacing of $2.13 \times 2.74$ $\mathrm{m}$ (vine $\times$ row; 1700 vines/ha) and a research vineyard (Oregon State University, Woodhall Research Vineyard; long. $44^{\circ} 20^{\prime} \mathrm{N}$, lat. $123^{\circ} 24^{\prime}$ W) planted in 1978 with spacing of $1.82 \times 2.74 \mathrm{~m}($ vine $\times$ row; 2005 vines $/$ ha $)$. Vines were grown on their own roots at Woodhall or grafted onto 101-14 Mgt rootstock at Benton Lane. Vine rows at both sites were oriented north-south. From 1981 onward, vines at Woodhall were not irrigated, whereas small doses of supplemental drip irrigation water ( 0 to $48 \mathrm{~L}$ per vine per year in late summer, as needed) had been applied to vines at Benton Lane since 2000. At both sites, vines were cane-pruned and trained with vertical shoot positioning. The soil surface directly beneath the vine rows $(\approx 1$-m wide strip) was kept weed-free during the growing season by glyphosate application. The soil at both vineyards was a Jory series (fine, mixed, active, mesic Xeric Haplohumult) with a surface $\mathrm{pH}$ of 5.5 to 6.0 ( 0 to $30 \mathrm{~cm}$ deep). Available soil P (Bray 1) at both sites historically ranged from 2 to $15 \mathrm{mg} \mathrm{P} / \mathrm{kg}$ soil. A routine petiole sample collected from Benton Lane at bloom in 2002 indicated that vines were potentially P-deficient $(1.0 \mathrm{~g} \mathrm{P} / \mathrm{kg}$ dry mass). Vines at Woodhall had adequate $\mathrm{P}$ based on leaf blade and petiole $\mathrm{P}$ values at bloom in 2001 and 2002 (both tissues greater than $3.0 \mathrm{~g} \mathrm{P} / \mathrm{kg}$ dry mass), but véraison samples in 2002 were low in P (leaf blade $1.6 \mathrm{~g} \mathrm{P} / \mathrm{kg}$ dry mass, petiole $0.9 \mathrm{~g} \mathrm{P} / \mathrm{kg}$ dry mass) (Schreiner et al., 2006). However, neither vineyard displayed leaf symptoms of $P$ deficiency in 2002 or at any time during our study. Local weather data for reference evapotranspiration, rainfall, and temperature were obtained from the Corvallis, OR, AgriMet station (http://www.usbr.gov/pn/agrimet) located $\approx 30 \mathrm{~km}$ north of both vineyards.

Experimental design and foliar spray treatments. Treatments were applied in a randomized block design using three treatments at the commercial vineyard (water, phosphite, phosphate) and two treatments at the research vineyard (water, phosphite). Four replicates $(n=4)$ were used at each site giving a total of 12 experimental units (plots) at the commercial vineyard and eight experimental units (plots) at the research vineyard. Each plot at Benton Lane was $\approx 0.5$ ha and consisted of four rows of treated vines (data were only collected from vines in the two middle rows of each plot). All plots at Woodhall were accommodated in two adjacent rows and each plot consisted of 10 continuous vines within a single row (data were only collected from the eight interior vines of each plot).

At Benton Lane, vines were sprayed using an air-blast sprayer with nozzles that directed spray at the grape canopy. Vines at Woodhall were sprayed using a backpack sprayer with the spray manually directed onto the leaves. Each year vines were sprayed three times: just after bloom (near the end of June), 1 month after bloom, and near the time of véraison (end of August). Sprays contained water, phosphite (NutriPhite ${ }^{\circledR}$ P Foliar; Biagro Western Sales, Inc., Visalia, CA), or phosphate. The phosphite product contained $4 \% \mathrm{~N}$ and $6.6 \% \mathrm{~K}$ (from $\mathrm{KOH}, \mathrm{NH}_{4} \mathrm{OH}$, and $\mathrm{K}$-citrate); therefore, the phosphate treatment was formulated using $\mathrm{NH}_{4} \mathrm{H}_{2} \mathrm{PO}_{4}$ and $\mathrm{KH}_{2} \mathrm{PO}_{4}$ to obtain identical quantities of $\mathrm{N}$ and $\mathrm{K}$ like in the phosphite treatment. Sprays containing $\mathrm{P}$ were applied in $888 \mathrm{~L} \cdot \mathrm{ha}^{-1}$ of water at a rate of $0.65 \mathrm{~kg} \mathrm{P} / \mathrm{ha}(0.20 \mathrm{~kg} \mathrm{~N} / \mathrm{ha}$, $0.32 \mathrm{~kg} \mathrm{~K} / \mathrm{ha}$ ). Each year, the quantity of $\mathrm{P}$ applied in the three sprays was equal to $\approx 50 \%$ of the yearly canopy demand for $\mathrm{P}$ (total content of shoots, leaves, and fruit) for a typical 'Pinot noir' vineyard in the region (Schreiner et al., 2006).

Plant measurements. The impact of foliar $\mathrm{P}$ applications was assessed by measuring leaf blade and petiole nutrient concentrations as indicators of vine nutrient status; dormant season pruning weight to indicate shoot growth; fine root density to indicate root growth; AMF colonization of fine roots; midday leaf water potential ( $\left.\Psi_{\text {leaf }}\right)$ and stomatal conductance $\left(g_{\mathrm{s}}\right)$ as measures of plant water status; fruit yield; and berry quality attributes (soluble solids, titratable acidity, $\mathrm{pH}$, juice P). Measurements of soil moisture content, vine nutrient and water status, fine root density, and colonization by AMF were recorded on consecutive days at each vineyard within $4 \mathrm{~d}$ of véraison: 20 and $21 \mathrm{Aug}$. 2003; 16 and 17 Aug. 2004; and 29 and 30 Aug. 2005. Sampling was focused at véraison because soil moisture is typically at its seasonal low point, vines experience water stress, and arbuscule frequency in roots is highest (Schreiner, 2005). Vine nutrient status was also determined in leaf blades and petioles at bloom in each year and in pruning wood at dormancy in 2003 and 2004.

Soil moisture content, fine root density, and AMF colonization of fine roots were determined from soil samples collected at véraison. Samples from each plot were comprised of three large soil cores $(6 \mathrm{~cm}$ diameter; 0 to $45 \mathrm{~cm}$ depth; $\approx 2 \mathrm{~kg}$ fresh weight) removed from the weed-free zone under the vine row. Soil moisture content was determined gravimetrically (Gardner, 1986) in subsamples $(\approx 50 \mathrm{~g})$ after thorough mixing. Roots were removed by hand directly from the soil and separated into woody and fine fractions as described in Schreiner (2005). Fine roots were stored in formaldehyde:acetic acid:ethanol (5\%:10\%:50\%) for up to 2 months before clearing and staining to evaluate AMF colonization. Roots were cleared using $\mathrm{KOH}$ and $\mathrm{H}_{2} \mathrm{O}_{2}$ and stained with trypan blue, as described in Schreiner (2003). Fine root length was determined by the gridline intercept method (Newman, 1966). Colonization of fine roots by AMF was determined on randomly selected root fragments mounted on slides using the method of McGonigle et al. (1990) as modified by Schreiner (2003). Percent AMF colonization is expressed as the proportion of fine root length containing any AMF structures (aseptate hyphae, vesicles, or arbuscules), and percent arbuscules is expressed as the pro- portion of fine root length containing only arbuscules.

Vine nutrient status at bloom and véraison was determined from leaf blades and petioles (analyzed separately), except that petioles were not available in 2003. Two leaf blades and petioles were collected from each sample vine $(\mathrm{n}=12$ at Benton Lane; $\mathrm{n}=8$ at Woodhall). Bloom-time samples used only opposite cluster leaves and petioles. Véraison samples consisted of one leaf collected from opposite a cluster and one leaf from a recently fully expanded leaf per vine sampled. At Benton Lane, leaves were collected from the middle two rows of each plot sampling every fifth or sixth vine and alternating between the rows with a minimum distance of $10 \mathrm{~m}$ from the plot edges. Woodhall samples were drawn from contiguous vines in each plot. Leaves were bagged, transported on ice, separated in the laboratory by leaf blade and petiole, rinsed repeatedly under running distilled water, and oven-dried at $70{ }^{\circ} \mathrm{C}$ for $5 \mathrm{~d}$. All dried plant parts were ground to pass through a 40 -mesh $(425 \mu \mathrm{m})$ screen and analyzed for nutrient concentrations. The $\mathrm{N}$ concentrations were determined by combustion analysis (CNS-2000 Macro Analyzer; Leco Inc., St. Louis, MO), whereas $\mathrm{P}, \mathrm{K}, \mathrm{Ca}, \mathrm{Mg}$, iron (Fe), manganese (Mn), B, copper, and $\mathrm{Zn}$ concentrations were determined by inductively coupled plasma optical emission spectrometry (Perkin Elmer Optima 3000DV, Wellesley, MA) after microwaveassisted digestion (Jones and Case, 1990).

$\Psi_{\text {leaf }}$ and $g_{\mathrm{s}}$ to water vapor were measured at véraison. $\Psi_{\text {leaf }}$ was measured with a pressure chamber (Model 610; PMS Instrument Co., Corvallis, OR). For each plot, two fully sun-exposed, undamaged leaves were selected from the middle of the sample shoot and placed in a plastic bag before severing the petiole. Measurements at each site were recorded within $1.5 \mathrm{~h}$ of solar noon on consecutive days with clear skies. In 2004 and $2005, g_{s}$ was measured with a diffusion porometer (LI-COR 1600; LI-COR Inc., Lincoln, NE) on the same leaf used to determine $\Psi_{\text {leaf }}$.

The fresh weight of dormant fruiting canes (pruning weight) was determined on the same vines as those used for fruit samples. Pruning weight data were not available for Woodhall in 2005. To assess whether treatments influenced nutrient storage in woody tissues, nutrient concentrations also were determined in subsamples of pruning wood representative of the 2003 and 2004 growing seasons following the same protocol as for leaves and petioles.

Fruit, juice, and wine measurements. Fruit was harvested 1 or $2 \mathrm{~d}$ before commercial harvest. All clusters were removed, counted, and weighed from five randomly selected vines per plot at Benton Lane and from the eight experimental vines per plot at Woodhall. Random subsamples of five clusters per plot were transported to the laboratory on ice, stored at $4{ }^{\circ} \mathrm{C}$, and processed for fruit constituents within $2 \mathrm{~d}$. Berries were removed from the rachis by hand and their 
juice extracted with a small hand-crank press, producing a juice yield of $625 \mathrm{~mL} \cdot \mathrm{kg}^{-1}$ fresh weight of fruit. Juice soluble solids $\left({ }^{\circ}\right.$ Brix) were measured with a handheld refractometer (Leica Microsystems, Buffalo, NY) and $\mathrm{pH}$ determined with a $\mathrm{pH}$ meter. Titratable acidity (TA) was determined by titration to a $\mathrm{pH}$ end point of 8.2. In 2003 and 2004, $\mathrm{PO}_{4}$ concentration in juice samples was determined with a colorimetric assay (Watanabe and Olsen, 1965), including appropriate blanks to account for interfering chromophores in the samples.

Wine lots were prepared in 2003 and 2004 from two field replicates at the commercial vineyard for a total of six each year. Fermentation conditions were uniform between years and included malolactic fermentation. Lots were maintained in separate barrels during aging and were bottled separately by field plot. The finished wines were evaluated by six people (2003 wines) or five people (2004 wines) using a series of four triangle tests (Meilgaard et al., 1999) conducted at the winery. Wine was poured into clear glasses for assessment of differences. Two comparisons were made between wine from control plots versus phosphate-treated plots, and two comparisons were made between wine from control plots versus phosphite-treated plots in each year. Tasting results were used to determine whether further chemometric analysis and expense were warranted.

Data analysis. All statistical analyses were conducted using Statistica software (Version 8.0; Statsoft Inc., Tulsa, OK). Data from each site were analyzed separately. All data were tested for homogeneity of variance using Levene's test and for normality using Kolmogorov-Smirnov test. Data for leaf blade concentrations of $\mathrm{Fe}, \mathrm{Mn}, \mathrm{B}$, and $\mathrm{Zn}$ from Benton Lane and $\mathrm{Fe}$ from Woodhall could not be transformed to satisfy assumptions of analysis of variance (ANOVA) and were analyzed using Kruskal-Wallis ANOVA by ranks and treatment means were compared using Kruskal-Wallis median comparison test at $P<$ 0.05 . All other data were analyzed by ANOVA using year and foliar spray treatment as factors and treatment means were compared using Tukey's post hoc test at $P<0.05$. Because the interaction between year and $\mathrm{P}$ treatment was not significant $(P>0.05)$ for any of the variables we measured at either site, only main effects are reported.

\section{Results}

Vine phenology and weather. The timing of vine development was similar at both sites with vines at Woodhall typically 1 or $2 \mathrm{~d}$ ahead of those at Benton Lane for the same phenological stage (Table 1). Years were different from one another; phenological stages occurred later in 2005 than 2003 or 2004 with bloom and véraison $\approx 9 \mathrm{~d}$ later and harvest $\approx 14 \mathrm{~d}$ later. Slower rates of development in 2005 were related to wet weather during May and June. From budbreak to bloom in 2005, rainfall was roughly twice that of either 2003 or 2004 . Thermal time (expressed as degree-days) accumulated during the same period was highest in 2005 because there were more days between budbreak and bloom. Reference evapotranspiration was similar across years, but the overall seasonal water deficit was highest in 2003. Before veraison, the primary period of interest, the seasonal water deficit was $608 \mathrm{~mm}$ (2003), $592 \mathrm{~mm}$ (2004), and $558 \mathrm{~mm}$ (2005).

Vine nutrient status. Leaf blade and petiole P concentrations at bloom time were not significantly altered by foliar spray treatments in either vineyard in any year (data not shown). At véraison, foliar spray treatments had no influence on vine $\mathrm{P}$ status at Benton Lane, but leaf blade and petiole $\mathrm{P}$

concentrations were increased in the phosphite-treated vines at Woodhall (Table 2). Leaf P concentrations were higher in 2004 and 2005 than in 2003 at both vineyards. Concentrations of macro- and micronutrients other than $\mathrm{P}$ in leaves and petioles were not significantly affected by foliar P sprays at either vineyard (data not shown). However, the concentrations of most nutrients in leaves and petioles varied significantly by year at both sites (Table 3 shows leaf blade data). Notably at both vineyards, $\mathrm{N}$ was highest and $\mathrm{K}$ was lowest in 2003; Fe, $\mathrm{Mn}$, and $\mathrm{B}$ were highest in 2004 and $\mathrm{Zn}$ was lowest in 2003 in leaves. None of the nutrients examined (including P) in pruning wood samples from

Table 1. Grapevine phenology in two vineyards and regional weather summary, 2003 to 2005

\begin{tabular}{|c|c|c|c|c|}
\hline \multirow[b]{2}{*}{ Site } & \multirow[b]{2}{*}{ Phenological stage } & 2003 & 2004 & 2005 \\
\hline & & \multicolumn{3}{|c|}{ Date reached $^{z}$} \\
\hline \multirow[t]{4}{*}{ Benton Lane } & Budbreak & 17 Apr. & 20 Apr. & 15 Apr. \\
\hline & Bloom & 19 June & 15 June & 26 June \\
\hline & Véraison & 21 Aug. & 15 Aug. & 28 Aug \\
\hline & Harvest & 22 Sept. & 23 Sept. & 10 Oct. \\
\hline \multirow[t]{4}{*}{ Woodhall } & Budbreak & 16 Apr. & 18 Apr. & 13 Apr. \\
\hline & Bloom & 17 June & 13 June & 24 June \\
\hline & Véraison & 18 Aug. & 14 Aug. & 25 Aug \\
\hline & Harvest & 22 Sept. & 24 Sept. & 4 Oct. \\
\hline Meteorological variable ${ }^{y}$ & Period $^{\mathrm{x}}$ & & & \\
\hline \multirow[t]{4}{*}{ Growing degree-days (greater than $10^{\circ} \mathrm{C}$ ) ${ }^{\mathrm{w}}$} & Budbreak-bloom & 306 & 262 & 340 \\
\hline & Bloom-véraison & 584 & 601 & 603 \\
\hline & Véraison-harvest & 269 & 316 & 268 \\
\hline & Budbreak-harvest & 1159 & 1179 & 1211 \\
\hline \multirow[t]{4}{*}{ ETo $(\mathrm{mm})^{\mathrm{v}}$} & Budbreak-bloom & 266 & 229 & 285 \\
\hline & Bloom-véraison & 451 & 469 & 471 \\
\hline & Véraison-harvest & 176 & 178 & 172 \\
\hline & Budbreak-harvest & 893 & 876 & 928 \\
\hline \multirow[t]{4}{*}{ Rainfall (mm) } & Budbreak-bloom & 101 & 101 & 194 \\
\hline & Bloom-véraison & 8 & 5 & 4 \\
\hline & Véraison-harvest & 25 & 105 & 56 \\
\hline & Budbreak-harvest & 134 & 211 & 254 \\
\hline$\underline{\text { Seasonal water deficit }(\mathrm{mm})^{\mathrm{u}}}$ & Budbreak-harvest & 759 & 665 & 674 \\
\hline
\end{tabular}

${ }^{z}$ The closest date when each growth stage occurred was determined by visually inspecting and recording growth stages of numerous vines throughout each vineyard conducted every $2 \mathrm{~d}$.

${ }^{y}$ Meteorological data obtained from AgriMet, Corvallis, OR (http://www.usbr.gov/pn/agrimet/); weather station located $\approx 30 \mathrm{~km}$ north of both vineyards.

${ }^{\mathrm{x}}$ Calculated from the date phenological stage occurred averaged over both sites.

${ }^{\mathrm{w}}$ Growing degree-days computed from the average daily low and high temperature with the lower threshold set at $10{ }^{\circ} \mathrm{C}$ and the upper threshold set at $30^{\circ} \mathrm{C}$.

${ }^{v}$ Reference evapotranspiration (ETo) computed by the Kimberly-Penman method (Wright, 1982).

uSeasonal water deficit equals ETo less rainfall.

Table 2. Vine phosphorus (P) status at véraison in two vineyards that received foliar sprays of water or P-containing compounds each growing season from 2003 to $2005 .^{\mathrm{z}}$

\begin{tabular}{|c|c|c|c|c|c|}
\hline \multirow[b]{2}{*}{ Factor } & \multirow[b]{2}{*}{ Level } & \multicolumn{2}{|c|}{ Benton Lane } & \multicolumn{2}{|c|}{ Woodhall } \\
\hline & & $\begin{array}{c}\text { Leaf } \\
\mathrm{P}\left(\mathrm{g} \cdot \mathrm{kg}^{-1}\right)\end{array}$ & $\begin{array}{c}\text { Petiole } \\
\mathrm{P}\left(\mathrm{g} \cdot \mathrm{kg}^{-1}\right)\end{array}$ & $\begin{array}{c}\text { Leaf } \\
\mathrm{P}\left(\mathrm{g} \cdot \mathrm{kg}^{-1}\right)\end{array}$ & $\begin{array}{c}\text { Petiole } \\
\mathrm{P}\left(\mathrm{g} \cdot \mathrm{kg}^{-1}\right)\end{array}$ \\
\hline \multirow[t]{3}{*}{ Year } & 2003 & $1.35(0.06) \mathrm{a}^{\mathrm{y}}$ & - & $1.64(0.04) \mathrm{a}$ & - \\
\hline & 2004 & $1.79(0.08) b$ & $1.63(0.16)$ & $2.07(0.09) \mathrm{b}$ & $2.39(0.09)$ \\
\hline & 2005 & $1.91(0.10) b$ & $1.98(0.21)$ & $1.97(0.09) \mathrm{b}$ & $2.21(0.14)$ \\
\hline \multicolumn{2}{|c|}{ ANOVA significance level } & $<0.001$ & 0.174 & 0.001 & 0.441 \\
\hline \multirow[t]{3}{*}{ Treatment } & Control & $1.67(0.11)$ & $2.10(0.24)$ & $1.78(0.05) \mathrm{y}$ & $2.09(0.14) \mathrm{y}$ \\
\hline & Phosphite $\left(\mathrm{PO}_{3}\right)$ & $1.75(0.12)$ & $1.88(0.27)$ & $2.00(0.09) \mathrm{z}$ & $2.50(0.12) \mathrm{Z}$ \\
\hline & Phosphate $\left(\mathrm{PO}_{4}\right)$ & $1.62(0.08)$ & $1.44(0.14)$ & - & - \\
\hline \multicolumn{2}{|c|}{ ANOVA significance level } & 0.632 & 0.118 & 0.013 & 0.031 \\
\hline
\end{tabular}

${ }^{z}$ Data represent mean values $( \pm$ SEM).

${ }^{y}$ Means followed by the same letter within each factor in a column are not significantly different based on Tukey's (honestly significant difference) at $95 \%$ confidence.

ANOVA = analysis of variance. 
Table 3. Concentrations of nutrients in 'Pinot noir' leaf blades at véraison in two vineyards from 2003 to $2005 .^{\mathrm{z}}$

\begin{tabular}{|c|c|c|c|c|c|c|}
\hline \multirow[b]{2}{*}{ Nutrient (units) } & \multicolumn{3}{|c|}{ Benton Lane } & \multicolumn{3}{|c|}{ Woodhall } \\
\hline & 2003 & 2004 & 2005 & 2003 & 2004 & 2005 \\
\hline Nitrogen $\left(\mathrm{g} \cdot \mathrm{kg}^{-1}\right)$ & $22.5(0.4) b^{y}$ & $20.5(0.2) \mathrm{a}$ & $21.1(0.4) \mathrm{a}$ & $24.7(0.3) \mathrm{z}$ & $23.0(0.5) \mathrm{y}$ & $22.6(0.4) y$ \\
\hline Potassium $\left(\mathrm{g} \cdot \mathrm{kg}^{-1}\right)$ & $9.9(0.3) \mathrm{a}$ & $14.5(0.5) \mathrm{c}$ & $11.8(0.3) \mathrm{b}$ & $8.1(0.2) \mathrm{y}$ & $10.0(0.2) \mathrm{z}$ & $10.0(0.3) \mathrm{z}$ \\
\hline Calcium (g. $\left.\mathrm{kg}^{-1}\right)$ & $18.5(0.4) \mathrm{a}$ & $16.9(0.6) \mathrm{a}$ & $20.9(0.5) b$ & $20.9(0.6) \mathrm{yz}$ & $23.3(0.6) \mathrm{z}$ & $19.1(0.7) \mathrm{y}$ \\
\hline $\operatorname{Magnesium}\left(\mathrm{g} \cdot \mathrm{kg}^{-1}\right)$ & $3.9(0.1) b$ & $3.4(0.2) \mathrm{a}$ & $4.2(0.1) b$ & $5.8(0.2)$ & $5.8(0.1)$ & $5.8(0.2)$ \\
\hline $\operatorname{Iron}^{\mathrm{x}}\left(\mathrm{mg} \cdot \mathrm{kg}^{-1}\right)$ & $98(3) a b$ & $152(12) b$ & 83 (2) a & $166(4) y z$ & $191(12) \mathrm{z}$ & $154(6) \mathrm{y}$ \\
\hline Manganese $^{\mathrm{x}}\left(\mathrm{mg} \cdot \mathrm{kg}^{-1}\right)$ & 265 (16) a & $571(80) b$ & $354(27) a b$ & $202(11) \mathrm{y}$ & $265(15) \mathrm{z}$ & $208(10) y$ \\
\hline Boron $^{\mathrm{x}}\left(\mathrm{mg} \cdot \mathrm{kg}^{-1}\right)$ & 24 (1) a & $34(2) b$ & $22(1) a$ & 27 (1) y & $32(2) \mathrm{z}$ & $24(1) \mathrm{y}$ \\
\hline $\operatorname{Zinc}^{\mathrm{x}}\left(\mathrm{mg} \cdot \mathrm{kg}^{-1}\right)$ & $13(1) \mathrm{a}$ & $20(2) b$ & $21(1) b$ & 13 (1) y & 19 (1) z & 18 (1) $\mathrm{z}$ \\
\hline Copper $\left(\mathrm{mg} \cdot \mathrm{kg}^{-1}\right)$ & $7(0.3) \mathrm{a}$ & $8(0.6) \mathrm{a}$ & $10(0.4) \mathrm{b}$ & $7(0.3)$ & $8(0.5)$ & $7(0.3)$ \\
\hline
\end{tabular}

${ }^{\mathrm{z}}$ Data represent mean values ( \pm SEM).

y Means followed by the same letter within each vineyard in a row are not significantly different based on Tukey's (honestly significant difference) or KruskalWallis median comparison at $95 \%$ confidence.

${ }^{x}$ Leaf blade iron, manganese, boron, and zinc at Benton Lane and iron at Woodhall were analyzed using Kruskal-Wallis analysis of variance (ANOVA) by ranks; all other nutrients were analyzed by ANOVA.

Table 4. Grapevine fine root density and colonization by AMF at véraison in two vineyards that received foliar sprays of water or phosphorus-containing compounds each growing season from 2003 to 2005 . $^{\mathrm{z}}$

\begin{tabular}{|c|c|c|c|c|c|c|c|}
\hline \multirow[b]{2}{*}{ Factor } & \multirow[b]{2}{*}{ Level } & \multicolumn{3}{|c|}{ Benton Lane } & \multicolumn{3}{|c|}{ Woodhall } \\
\hline & & $\begin{array}{c}\text { Fine root } \\
\text { length }\left(\mathrm{mm} \cdot \mathrm{g}^{-1}\right)\end{array}$ & $\begin{array}{c}\% \\
\mathrm{AMF}\end{array}$ & $\begin{array}{c}\% \\
\text { Arbuscules }\end{array}$ & $\begin{array}{c}\text { Fine root } \\
\text { length }\left(\mathrm{mm} \cdot \mathrm{g}^{-1}\right)\end{array}$ & $\begin{array}{c}\% \\
\mathrm{AMF}\end{array}$ & $\begin{array}{c}\% \\
\text { Arbuscules }\end{array}$ \\
\hline \multirow[t]{3}{*}{ Year } & 2003 & $0.43(0.06)$ & $89.2(2.4)$ & $12.8(2.6)$ & $0.26(0.05) \mathrm{ab}^{\mathrm{y}}$ & $83.6(4.3)$ & $34.9(3.5) b$ \\
\hline & 2004 & $0.39(0.06)$ & $88.3(1.8)$ & $19.5(2.1)$ & $0.41(0.06) \mathrm{b}$ & $84.4(3.4)$ & $31.0(3.4) b$ \\
\hline & 2005 & $0.39(0.04)$ & $91.7(1.5)$ & $12.8(2.1)$ & $0.14(0.03) \mathrm{a}$ & $70.5(4.3)$ & $11.5(2.3) \mathrm{a}$ \\
\hline \multicolumn{2}{|c|}{ ANOVA significance level } & 0.868 & 0.480 & 0.075 & 0.003 & 0.052 & $<0.001$ \\
\hline \multirow[t]{3}{*}{ Treatment } & Control & $0.38(0.06)$ & $90.1(1.8)$ & $18.6(2.7)$ & $0.24(0.04)$ & $77.2(3.7)$ & $31.5(4.2) \mathrm{z}$ \\
\hline & Phosphite $\left(\mathrm{PO}_{3}\right)$ & $0.40(0.04)$ & $87.7(2.2)$ & $12.4(1.9)$ & $0.30(0.05)$ & $81.8(3.7)$ & $20.1(2.8) \mathrm{y}$ \\
\hline & Phosphate $\left(\mathrm{PO}_{4}\right)$ & $0.43(0.06)$ & $91.4(1.9)$ & $14.2(2.3)$ & - & - & - \\
\hline \multicolumn{2}{|c|}{ ANOVA significance level } & 0.795 & 0.430 & 0.163 & 0.294 & 0.345 & $<0.001$ \\
\hline
\end{tabular}

${ }^{\mathrm{z}}$ Data represent mean values $( \pm$ SEM).

${ }^{y}$ Means followed by the same letter within each factor in a column are not significantly different based on Tukey's (honestly significant difference) at $95 \%$ confidence.

$\mathrm{AMF}=$ arbuscular mycorrhizal fungi; ANOVA = analysis of variance.

2003 and 2004 from either vineyard were altered by foliar P sprays (data not shown).

Roots, arbuscular mycorrhizal fungi colonization, and soil and vine water status. Neither year nor foliar P sprays influenced fine root length density or AMF colonization in roots at Benton Lane (Table 4). Root density was similarly unaffected by foliar P treatment at Woodhall, but there was a lower percentage of roots with arbuscules in response to phosphite application. Additionally, fine root density was lower in 2005 than in 2004, and arbuscules in roots were lower in 2005 than in either 2003 or 2004, most likely a consequence of the milder weather and higher vine water status (see subsequently), in agreement with previous work in the region (Schreiner and Linderman, 2005; Schreiner et al., 2007).

Soil and vine water status were unaffected by foliar P treatments at either vineyard, although year had a significant effect (Table 5). Soil water content at véraison was highest in 2005 at both sites, reflected in the higher $\Psi_{\text {leaf }}$ and $g_{\mathrm{s}}$ values also in 2005 .

Vine growth, fruit yield, and quality. Vine growth and fruit yield were unaffected by foliar P treatments at either vineyard, although year had a significant effect (Table 6). At Benton Lane, pruning weights were highest in 2005. At Woodhall, vines were more vigorous in 2004 than in 2003. Data were not available for 2005. Yield was lowest in 2004 at Benton Lane, whereas at Woodhall, yield was lowest in 2005 following a sequential decline $(2003>2004>2005)$ attributable to differences in average mass per cluster. High yield at both sites in 2003 was attributable largely to good fruit set that year resulting in large clusters $(\approx 2 \times$ the average cluster mass of either 2004 or 2005).

Basic fruit chemistry metrics varied by year at both vineyards, although effects were not consistent between sites (Table 7). Fruit from Benton Lane had higher soluble solids and lower TA in 2005 than either 2003 or 2004 , largely attributable to the late harvest in 2005. Fruit from Woodhall had higher soluble solids in 2003 than 2005 and lower TA in 2003 than both 2004 and 2005. Foliar P as phosphite was associated with higher soluble solids in the fruit only at Woodhall. At both sites, foliar P sprays did not significantly affect juice phosphate concentrations in either 2003 or 2004, although concentrations were $13 \%$ higher in 2004 than 2003 at Benton Lane $(59 \mathrm{mg} \mathrm{P} / \mathrm{L}$ versus $52 \mathrm{mg} \mathrm{P} / \mathrm{L}$ as phosphate) and $14 \%$ higher in 2004 than 2003 at Woodhall $(66 \mathrm{mg} \mathrm{P} / \mathrm{L}$ versus $58 \mathrm{mg}$ $\mathrm{P} / \mathrm{L}$ as phosphate). Informal triangle tests of wines resulted in only nine correct choices out of 24 total for the 2003 vintage and seven correct choices out of 20 total for the 2004 vintage. These values are well below what is significant for a triangle test (Meilgaard et al., 1999), because there is a $33 \%$ chance of guessing correctly in each set of three wines. Therefore, further chemometric analysis of the wines was not pursued.

\section{Discussion}

The primary purpose of this work was to investigate whether application of $\mathrm{P}$ to the leaves of grapevines would increase vine $\mathrm{P}$ status and as a consequence reduce AMF colonization in roots. Less AMF colonization potentially increases vine water stress during late summer, a typically rain-free period in western Oregon. Our results were not conclusive. At the commercial vineyard, vine $\mathrm{P}$ status was not improved by foliar P sprays and AMF colonization of roots was unaffected. Only at the research vineyard was vine $\mathrm{P}$ status improved (P concentration was increased by $8 \%$ in leaves and $19 \%$ in petioles at véraison), a small change that induced lower arbuscular colonization. These results confirm previous findings that foliar $\mathrm{P}$ enrichment can reduce AMF colonization in vineyards (Schreiner and Linderman, 2005) and that the response can be attributed to an increase in vine $\mathrm{P}$ status. However, the reduction in arbuscules in roots did not influence indicators of vine water status nor did it influence the concentration of other nutrients in leaves and petioles. Therefore, it is unlikely that application of foliar P fertilizers in vineyards will lead to a large enough reduction in AMF colonization that vines would be subjected to more severe drought stress or reduced uptake of other key nutrients.

The use of phosphite-based products as a source of $\mathrm{P}$ nutrition is not recommended 
Table 5. Soil moisture and grapevine water status at véraison in two vineyards that received foliar sprays of water or phosphorus-containing compounds each growing season from 2003 to $2005 .^{z}$

\begin{tabular}{|c|c|c|c|c|c|c|c|}
\hline \multirow[b]{2}{*}{ Factor } & \multirow[b]{2}{*}{ Level } & \multicolumn{3}{|c|}{ Benton Lane } & \multicolumn{3}{|c|}{ Woodhall } \\
\hline & & $\begin{array}{c}\text { Soil water } \\
\text { content }\left(\mathrm{g} \cdot \mathrm{kg}^{-1}\right)\end{array}$ & $\begin{array}{l}\text { Leaf } \Psi \\
(\mathrm{MPa})\end{array}$ & $\begin{array}{c}g_{\mathrm{s}} \\
\left(\mathrm{mmol} \cdot \mathrm{m}^{-2} \cdot \mathrm{s}^{-1}\right)\end{array}$ & $\begin{array}{c}\text { Soil water } \\
\text { content }\left(\mathrm{g} \cdot \mathrm{kg}^{-1}\right)\end{array}$ & $\begin{array}{l}\operatorname{Leaf} \Psi \\
(\mathrm{MPa})\end{array}$ & $\begin{array}{c}g_{\mathrm{s}} \\
\left(\mathrm{mmol} \cdot \mathrm{m}^{-2} \cdot \mathrm{s}^{-1}\right)\end{array}$ \\
\hline \multirow[t]{3}{*}{$\overline{\text { Year }}$} & 2003 & $196(5) a^{y}$ & $-1.32(0.03) \mathrm{a}$ & - & $130(3) \mathrm{a}$ & $-1.26(0.02) \mathrm{a}$ & - \\
\hline & 2004 & $212(5) a b$ & $-1.22(0.03) \mathrm{a}$ & $253(22) \mathrm{a}$ & $125(3) \mathrm{a}$ & $-1.22(0.01) \mathrm{a}$ & 355 (16) a \\
\hline & 2005 & $219(4) b$ & $-0.84(0.03) b$ & $567(38) b$ & $144(3) b$ & $-0.98(0.01) b$ & $600(18) b$ \\
\hline \multicolumn{2}{|c|}{ ANOVA significance level } & 0.006 & $<0.001$ & $<0.001$ & 0.002 & $<0.001$ & $<0.001$ \\
\hline \multirow[t]{3}{*}{ Treatment } & Control & $214(5)$ & $-1.11(0.08)$ & $420(69)$ & $135(4)$ & $-1.15(0.04)$ & $483(48)$ \\
\hline & Phosphite $\left(\mathrm{PO}_{3}\right)$ & $212(2)$ & $-1.09(0.06)$ & $433(63)$ & $131(3)$ & $-1.15(0.04)$ & $472(50)$ \\
\hline & Phosphate $\left(\mathrm{PO}_{4}\right)$ & $202(4)$ & $-1.15(0.07)$ & $375(78)$ & - & - & - \\
\hline \multicolumn{2}{|c|}{ ANOVA significance level } & 0.156 & 0.355 & 0.592 & 0.338 & 0.911 & 0.682 \\
\hline
\end{tabular}

${ }^{\mathrm{z}}$ Data represent mean values ( \pm SEM).

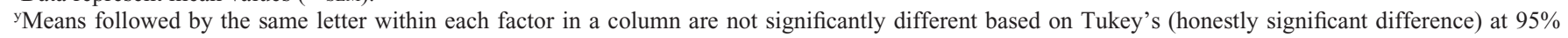
confidence.

$\Psi=$ water potential; $g_{\mathrm{s}}=$ stomatal conductance; ANOVA $=$ analysis of variance.

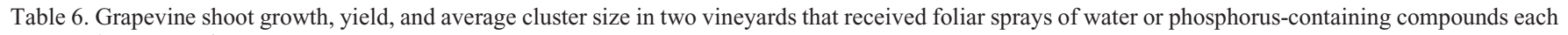
growing season from 2003 to $2005 .^{\mathrm{z}}$

\begin{tabular}{|c|c|c|c|c|c|c|c|}
\hline \multirow[b]{2}{*}{ Factor } & \multirow[b]{2}{*}{ Level } & \multicolumn{3}{|c|}{ Benton Lane } & \multicolumn{3}{|c|}{ Woodhall } \\
\hline & & $\begin{array}{c}\text { Pruning } \\
\text { mass }(\mathrm{kg})\end{array}$ & Yield (kg) & $\begin{array}{c}\text { Cluster } \\
\text { mass (g) }\end{array}$ & $\begin{array}{c}\text { Pruning } \\
\text { mass }(\mathrm{kg})\end{array}$ & Yield (kg) & $\begin{array}{c}\text { Cluster } \\
\text { mass }(\mathrm{g})\end{array}$ \\
\hline \multirow[t]{3}{*}{ Year } & 2003 & $0.98(0.06) \mathrm{a}^{\mathrm{y}}$ & $4.29(0.15) \mathrm{b}$ & $161(5) b$ & $0.75(0.03) \mathrm{a}$ & $4.22(0.08) \mathrm{c}$ & $172(3) \mathrm{c}$ \\
\hline & 2004 & $1.05(0.04) \mathrm{a}$ & $2.26(0.10) \mathrm{a}$ & 79 (3) a & $1.04(0.04) \mathrm{b}$ & $2.49(0.11) b$ & $77(3) b$ \\
\hline & 2005 & $1.54(0.05) b$ & $3.94(0.24) b$ & 90 (4) a & - & $1.92(0.09) \mathrm{a}$ & $65(3) a$ \\
\hline \multicolumn{2}{|c|}{ ANOVA significance level } & $<0.001$ & $<0.001$ & $<0.001$ & $<0.001$ & $<0.001$ & $<0.001$ \\
\hline \multirow[t]{3}{*}{ Treatment } & Control & $1.19(0.09)$ & $3.46(0.34)$ & $107(10)$ & $0.92(0.07)$ & $2.86(0.31)$ & $104(15)$ \\
\hline & Phosphite $\left(\mathrm{PO}_{3}\right)$ & $1.19(0.09)$ & $3.57(0.30)$ & $115(12)$ & $0.88(0.06)$ & $2.89(0.29)$ & $105(14)$ \\
\hline & Phosphate $\left(\mathrm{PO}_{4}\right)$ & $1.19(0.10)$ & $3.45(0.32)$ & $108(12)$ & - & - & - \\
\hline \multicolumn{2}{|c|}{ ANOVA significance level } & 0.994 & 0.857 & 0.183 & 0.077 & 0.789 & 0.626 \\
\hline
\end{tabular}

${ }^{\mathrm{z}}$ Data represent mean values $( \pm$ SEM).

${ }^{y}$ Means followed by the same letter within each factor in a column are not significantly different based on Tukey's (honestly significant difference) at $95 \%$ confidence.

ANOVA = analysis of variance.

Table 7. Juice quality characteristics of 'Pinot noir' grapes harvested from two vineyards that received foliar sprays of water or phosphorus-containing compounds each growing season from 2003 to 2005 . $^{\mathrm{z}}$

\begin{tabular}{|c|c|c|c|c|c|c|c|}
\hline \multirow[b]{2}{*}{ Factor } & \multirow[b]{2}{*}{ Level } & \multicolumn{3}{|c|}{ Benton Lane } & \multicolumn{3}{|c|}{ Woodhall } \\
\hline & & $\begin{array}{c}\text { Soluble } \\
\text { solids ( }{ }^{\circ} \text { Brix) }\end{array}$ & $\mathrm{pH}$ & $\begin{array}{c}\text { Titratable } \\
\text { acidity }\left(\mathrm{g} \cdot \mathrm{L}^{-1}\right)\end{array}$ & $\begin{array}{c}\text { Soluble } \\
\text { solids ( }{ }^{\circ} \text { Brix) }\end{array}$ & $\mathrm{pH}$ & $\begin{array}{c}\text { Titratable } \\
\text { acidity }\left(\mathrm{g} \cdot \mathrm{L}^{-1}\right)\end{array}$ \\
\hline \multirow[t]{3}{*}{ Year } & 2003 & $23.3(0.2) \mathrm{a}^{\mathrm{y}}$ & $3.25(0.02)$ & $6.76(0.10) \mathrm{b}$ & $24.4(0.2) b$ & $3.31(0.02) \mathrm{b}$ & $6.97(0.09) \mathrm{a}$ \\
\hline & 2004 & $23.5(0.2) \mathrm{a}$ & $3.29(0.01)$ & $7.12(0.11) b$ & $24.3(0.1) \mathrm{ab}$ & $3.32(0.02) b$ & $7.64(0.15) b$ \\
\hline & 2005 & $24.6(0.2) \mathrm{b}$ & $3.31(0.01)$ & $6.10(0.16) \mathrm{a}$ & $24.0(0.1) \mathrm{a}$ & $3.20(0.02) \mathrm{a}$ & $7.67(0.15) b$ \\
\hline \multicolumn{2}{|c|}{ ANOVA significance level } & $<0.001$ & 0.066 & $<0.001$ & 0.039 & $<0.001$ & 0.002 \\
\hline \multirow[t]{3}{*}{ Treatment } & Control & $23.7(0.2)$ & $3.31(0.02)$ & $6.70(0.12)$ & $24.0(0.1) \mathrm{y}$ & $3.29(0.02)$ & $7.52(0.16)$ \\
\hline & Phosphite $\left(\mathrm{PO}_{3}\right)$ & $24.0(0.2)$ & $3.27(0.02)$ & $6.64(0.17)$ & $24.5(0.1) \mathrm{z}$ & $3.27(0.02)$ & $7.34(0.12)$ \\
\hline & Phosphate $\left(\mathrm{PO}_{4}\right)$ & $23.7(0.3)$ & $3.28(0.02)$ & $6.64(0.23)$ & - & - & - \\
\hline \multicolumn{2}{|c|}{ ANOVA significance level } & 0.130 & 0.171 & 0.902 & 0.004 & 0.499 & 0.224 \\
\hline
\end{tabular}

${ }^{\mathrm{z}}$ Data represent mean values $( \pm$ SEM).

${ }^{y}$ Means followed by the same letter within each factor in a column are not significantly different based on Tukey's (honestly significant difference) at $95 \%$ confidence.

ANOVA $=$ analysis of variance.

because plants cannot metabolize phosphite (Carswell et al., 1996). Evidence in the literature supports a supposition that the phosphite absorbed by the foliage in this study remained as phosphite within the plant (Carswell et al., 1996; Thao et al., 2008). In all plant species examined to date, phosphite appears to be stable, in which it is transported through the phloem and acts as an effective systemic plant fungicide (Guest and Grant, 1991). Indeed, the long-term efficacy (up to 2 years) of phosphite as a fungicide in several native trees (Tynan et al., 2001) suggests that phosphite in grapevines also will not be converted to phosphate over a period of years. Nonetheless, we cannot rule out the possibility that phosphite was oxidized to phosphate on the leaf surface and absorbed as phosphate. This may occur in dusty vineyards, where soil microflora are deposited on leaf surfaces. Phosphite can be oxidized to phosphate by soil microbes over a timeframe of weeks to months (McDonald et al., 2001). Phosphite added to hydroponically grown grapevines was rapidly ( 2 to $3 \mathrm{~d}$ ) oxidized to phosphate in an aerated (but not sterile) nutrient solution (Schreiner, unpublished data), indicating that rapid conversion to phosphate is possible. Indeed, this probably explains why Thao et al. (2008), investigating phosphite as a sole source of $\mathrm{P}$, did not aerate their hydroponically grown plants, which is common practice for hydroponic culture. Phosphite and phosphate were not distinguished in our leaf and petiole 
samples analyzed by inductively coupled plasma.

At this time, it would be prudent to advise growers that phosphite absorbed by the foliage will likely remain as phosphite, a nonusable source of $\mathrm{P}$ that can suppress the normal $\mathrm{P}$ starvation response, thus reducing the vines' ability to acquire phosphate and maintain normal P metabolism. However, some level of phosphite within plant tissues may provide a benefit by inhibiting certain pathogenic organisms, particularly Oomycetes (Guest and Grant, 1991).

The divergent responses to foliar $\mathrm{P}$ at the two vineyards studied here may be attributed to application method. Hand-spraying (Woodhall) by nature is more precise; one ensures that all of the material sprayed is deposited on the canopy (leaves). This was not the case with the air-blast sprayer at the commercial site, in which product deposition is much less controlled. The actual volume of spray deposited on the foliage at Benton Lane was not determined but could be expected to average $\approx 50 \%$ (Matthews, 2000). Regardless of nutrient being applied, it may be advisable to increase the dose of fertilizer to account for the spray volume that was not deposited on the canopy. Nonetheless, the small effect observed at Woodhall suggests that $\mathrm{P}$ is not efficiently or cost-effectively applied as a foliar fertilizer in commercial vineyards.

Despite little published work on foliar P in vineyards, the small increase in leaf blade and petiole $\mathrm{P}$ concentrations in vines at Woodhall and lack of effect at Benton Lane generally confirm the weak or inefficient responses to foliar P sprays across a number of horticultural crops (Swietlik and Faust, 1984). Bester and Meynhardt (1968) used ${ }^{32} \mathrm{P}$ to show that foliar $\mathrm{P}$ can be absorbed by grapevine leaves when applied in small patches surrounded by lanolin. However, their work did not apply to field conditions. Saleh et al. (2007) showed that multiple applications (every $10 \mathrm{~d}$ ) of $\mathrm{KH}_{2} \mathrm{PO}_{4}$ to the canopy of 'Thompson Seedless' increased leaf $\mathrm{P}$ concentrations and fruit yield. In that study, the specific treatments that improved vine $\mathrm{P}$ status were not always consistent with the ones that improved yield. Leaf P concentrations of 'Thompson Seedless' were improved from $0.9 \mathrm{mg} \mathrm{P} / \mathrm{kg}$ dry mass in the untreated control to 1.1 to $1.5 \mathrm{mg} \mathrm{P} / \mathrm{kg}$ dry mass in the phosphate-treated vines. In the present study, leaf blade $\mathrm{P}$ concentrations in the untreated 'Pinot noir' vines were above $1.3 \mathrm{mg} \mathrm{P} / \mathrm{kg}$ dry mass in all years. The lowest $P$ values occurred in 2003, the year with the greatest yield at each site, suggesting that véraison leaf blade $P$ values above $1.3 \mathrm{~g} \mathrm{P} / \mathrm{kg}$ dry mass indicate an adequate $\mathrm{P}$ status for 'Pinot noir' vines grown in the region. It is possible that foliar P sprays could have been more effective in this study had the vines been clearly deficient in $\mathrm{P}$ or had more numerous applications of $\mathrm{P}$ been made. The increase in vine $\mathrm{P}$ concentrations in leaves and petioles (Woodhall) did not carry into the fruit and increase $P$ in the juice nor into the woody canes assessed at dormancy.
The year or vintage effect was far larger than treatment effects, further evidence that growers should approach with caution the use of foliar P sprays. Weather drove differences in soil moisture and vine water status (e.g., 2005 was cooler and wetter), but year effects on nutrients were observed that did not coincide with variation in weather. For example, vines in 2003 had high $\mathrm{N}$ status but low $\mathrm{P}$, $\mathrm{K}$, and Zn status, whereas vines in 2004 had high $\mathrm{Fe}, \mathrm{Mn}$, and $\mathrm{B}$ compared with other years. Weather patterns were more similar in 2003 and 2004 and vine phenological development was more closely aligned between 2003 and 2004 than between 2005 and either 2003 or 2004 . Yet 2005 did not stand out as the year with a different nutrient status. However, the low P and $\mathrm{K}$ status in 2003 was consistent with 2003 being the overall driest year in this study. In wine grapes, diminished $\mathrm{P}$ and $\mathrm{K}$ status in response to drier soil conditions (examined in irrigation trials) is known to occur (Hepner and Bravdo, 1985; Klein et al., 2000; Sipiora et al., 2005). High tissue $\mathrm{N}$ observed in 'Pinot noir' in 2003 indicates that in dry years, vine $\mathrm{P}$ and $\mathrm{K}$ uptake is more strongly affected than is $\mathrm{N}$ uptake. Previous work at Woodhall vineyard using destructive whole-vine harvests showed that $\mathrm{P}$ uptake from soil was reduced more than $\mathrm{N}$ or $\mathrm{K}$ uptake in a dry versus a wet growing season (Schreiner et al., 2006).

\section{Conclusions}

Spraying grapevine canopies with $\mathrm{P}$ as a source of fertilizer does not appear to be an effective means to improve $\mathrm{P}$ nutrition in vineyards on a commercial scale. We applied a large amount of $\mathrm{P}$ to the canopy in this trial (equivalent to $50 \%$ of total canopy demand) and observed no increase in plant $\mathrm{P}$ status at a commercial vineyard. There was only a marginal increase in tissue $\mathrm{P}$ status at the research vineyard where foliar deposition was close to $100 \%$ as a result of the use of a hand-sprayer, an application that is not feasible commercially. Although the application of phosphite to the leaves of 'Pinot noir' was associated with lower frequency of arbuscules in roots, this change in AMF colonization was not associated with a change in vine water status nor was it related to lower uptake of other nutrients. It can be concluded that the small negative effect of foliar $\mathrm{P}$ sprays observed on AMF colonization will likely have little impact on overall vine physiology or fruit quality.

\section{Literature Cited}

Augé, R.M. 2001. Water relations, drought and vesicular-arbuscular mycorrhizal symbiosis. Mycorrhiza 11:3-42.

Bester, A.J. and J.T. Meynhardt. 1968. A study of some factors influencing the foliar uptake of phosphorus by grape vines. S. Afr. J. Agr. Sci. 11:477-481.

Carswell, C., B.R. Grant, M.E. Theodorou, J. Harris, J.O. Niere, and W.C. Plaxton. 1996. The fungicide phosphonate disrupts the phosphate-starvation response in Brassica nigra seedlings. Plant Physiol. 110:105-110.
Cheng, L., T. Henick-Kling, A. Lakso, and T. Martinson. 2003. Impact of foliar nitrogen at véraison and irrigation on Riesling fruit characteristics. Amer. J. Enol. Viticult. 54:139A.

Christensen, L.P. 2005. Foliar fertilization in vine mineral nutrition management programs, $\mathrm{p}$. 83-90. In: Christensen, L.P. and D.R. Smart (eds.). Proc. of the Soil Environment and Vine Mineral Nutrition Symposium. American Society for Enology and Viticulture, Davis, CA.

Christensen, L.P., A.N. Kasimatis, and F.L. Jensen. 1978. Grapevine nutrition and fertilization in the San Joaquin Valley. Publication 4087. University of California, Division of Agricultural Sciences, Berkeley, CA.

Cook, J.A. 1966. Grape nutrition, p. 777-812. In: Childers, N.F. (ed.). Nutrition of fruit crops Somerset Press, Somerville, NJ.

Cook, J.A., W.R. Ward, and A.S. Wicks. 1983. Phosphorus deficiency in California vineyards. Calif. Agr. 37:16-18.

Danova-Alt, R., C. Dijkema, P. DeWaard, and M. Köck. 2008. Transport and compartmentation of phosphite in higher plant cells - Kinetic and ${ }^{31} \mathrm{P}$ nuclear magnetic resonance studies. Plant Cell Environ. 31:1510-1521.

Dong, S., D. Neilsen, G.H. Neilsen, and L.H Fuchigami. 2005. Foliar N application reduces soil $\mathrm{NO}_{3}-\mathrm{N}$ leaching loss in apples orchards. Plant Soil 268:357-366.

Embleton, T.W. and W.W. Jones. 1974. Foliarapplied nitrogen for citrus fertilization. J. Environ. Qual. 3:388-391.

Gardner, W.H. 1986. Water content, p. 493-544. In: Klute, A. (ed.). Methods of soil analysis. Part I. Physical and mineralogical methods. American Society of Agronomy, Madison, WI.

Gärtel, W. 1996. Grapes, p. 177-183. In: Bennett, W.F. (ed.). Nutrient deficiencies and toxicities in crop plants. APS Press, St. Paul, MN.

Guest, D.I. and B.R. Grant. 1991. The complex action of phosphonates as antifungal agents. Biol. Rev. Camb. Philos. Soc. 66:159-187.

Hepner, Y. and B. Bravdo. 1985. Effect of crop level and drip irrigation scheduling on the potassium status of Cabernet Sauvignon and Carignane vines and its influence on must and wine composition and quality. Amer. J. Enol. Viticult. 36:140-147.

Jones, J.B. and V.W. Case. 1990. Sampling, handling, and analyzing plant tissue samples, $\mathrm{p}$. 389-427. In: Westerman, R.L. (ed.). Soil testing and plant analysis. 3rd Ed. Soil Science Society of America, Madison, WI.

Kasimatis, A.N. and L.P. Christensen. 1976. Response of Thompson Seedless grapevines to potassium application from three fertilizer sources. Amer. J. Enol. Viticult. 27:145-149.

Klein, I., M. Strime, L. Fanberstein, and Y. Mani. 2000. Irrigation and fertigation effects on phosphorus and potassium nutrition of wine grapes. Vitis 39:55-62.

Knoll, M., D. Achleiter, and H. Redl. 2006. Response of Zweigelt grapevine to foliar application of potassium fertilizer: Effects on gas exchange, leaf potassium content, and incidence of traubenwelke. J. Plant Nutr. 29: 1805-1817.

Koide, R.T. and R.P. Schreiner. 1992. Regulation of the vesicular-arbuscular mycorrhizal symbiosis. Annu. Rev. Plant Physiol. Plant Mol. Biol. 43:557-581.

Matthews, G.A. 2000. Pesticide application methods. 3rd Ed. Blackwell Science, Oxford, UK.

McDonald, A.E., B.R. Grant, and W.C. Plaxton. 2001. Phosphite (phosphorous acid): Its 
relevance in the environment and agriculture and influence on plant phosphate starvation response. J. Plant Nutr. 24:1505-1519.

McGonigle, T.P., M.H. Miller, D.G. Evans, G.L. Fairchild, and J.A. Swan. 1990. A new method which gives an objective measure of colonization of roots by vesicular-arbuscular mycorrhizal fungi. New Phytol. 115:495-501.

Meilgaard, M., G.V. Civille, and B.T. Carr. 1999. Sensory evaluation techniques. 3rd Ed. CRC Press, Boca Raton, FL.

Newman, E.I. 1966. A method of estimating the total length of root in a sample. J. Appl. Ecol. 3:139-145.

Robinson, J.B. 2005. Critical plant tissue values and application of nutritional standards for practical use in vineyards, p. 61-68. In: Christensen, L.P. and D.R. Smart (eds.). Proc. of the Soil Environment and Vine Mineral Nutrition Symposium. American Society for Enology and Viticulture, Davis, CA.

Robinson, J.B. and M.G. McCarthy. 1985. Use of petiole analysis for assessment of vineyard nutrient status in the Barossa district of South Australia. Aust. J. Exp. Agr. 25:231240 .

Saleh, M.M.S., N.E. Ashour, M.H. El-Sheikh, and M.A.A. El-Naggar. 2007. Foliar sprays of potassium dihydrogen phosphate and their impact on yield, fruit quality and controlling powdery mildew disease of Thompson Seed- less grapevines. American-Eurasian J. Agr. Environ. Sci. 2:133-140.

Schreiner, R.P. 2003. Mycorrhizal colonization of grapevine rootstocks under field conditions. Amer. J. Enol. Viticult. 54:143-149.

Schreiner, R.P. 2005. Spatial and temporal variation of roots, arbuscular mycorrhizal fungi, and plant and soil nutrients in a mature Pinot noir (Vitis vinifera L.) vineyard in Oregon, USA. Plant Soil 276:219-234.

Schreiner, R.P. 2007. Effects of native and nonnative arbuscular mycorrhizal fungi on growth and nutrient uptake of 'Pinot noir' (Vitis vinifera L.) in two soils with contrasting levels of phosphorus. Appl. Soil Ecol. 36:205-215.

Schreiner, R.P. and R.G. Linderman. 2005. Mycorrhizal colonization in dryland vineyards of the Willamette Valley, Oregon. Small Fruits Rev. 4:41-55.

Schreiner, R.P., C.F. Scagel, and J. Baham. 2006. Nutrient uptake and distribution in a mature 'Pinot noir' vineyard. HortScience 41:336-345.

Schreiner, R.P., J.M. Tarara, and R.P. Smithyman. 2007. Deficit irrigation promotes colonization of fine roots by mycorrhizal fungi in grapevines (Vitis vinifera L.) in an arid climate. Mycorrhiza 17:551-562.

Sipiora, M.J., M.M. Anderson, and M.A. Matthews. 2005. A role of irrigation in managing vine potassium status on a clay soil, p. 175-183. In: Christensen, L.P. and D.R. Smart (eds.). Proc. of the Soil Environment and Vine Mineral Nutrition Symposium. American Society for Enology and Viticulture, Davis, CA.

Swietlik, D. and M. Faust. 1984. Foliar nutrition of fruit crops. Hort. Rev. (Amer. Soc. Hort. Sci.) 6:287-355.

Thao, H.T.B., T. Yamakawa, K. Shibata, P.S. Sarr, and A.K. Myint. 2008. Growth response of komatsu (Brassica rapa var. peruviridis) to root and foliar applications of phosphite. Plant Soil 308:1-10.

Ticconi, C.A. and S. Abel. 2004. Short on phosphate: Plant surveillance and countermeasures. Trends Plant Sci. 9:548-555.

Tynan, K.M., C.J. Wilkinson, J.M. Holmes, B. Dell, I.J. Colquhoun, J.A. McComb, G.E. St, and J. Hardy. 2001. The long-term ability of phosphite to control Phytopthora cinnamomi in two native plant communities of Western Australia. Aust. J. Bot. 49:761-770.

Varadarajan, D.K., A.S. Karthikeyan, P.D. Matilda, and K.G. Raghothama. 2002. Phosphite, an anolog of phosphate, suppresses the coordinated expression of genes under phosphate starvation. Plant Physiol. 129:1232-1240.

Watanabe, F.S. and S.R. Olsen. 1965. Test of an ascorbic acid method for determining phosphorus in water and $\mathrm{NaHCO}_{3}$ extracts from soil. Soil Sci. Soc. Am. Proc. 29:677-678.

Wright, J.L. 1982. New evapotranspiration crop coefficients. J. Irrig. Drain. Div. 108:57-74. 